\title{
Urban space recovery. Landscape-beneficial solutions in new estates built in post-industrial and post-military areas in Bristol, Poznań and Gdańsk
}

\begin{abstract}
The limitation of territorial expansion and the implementation of the idea of a compact city are generally accepted paradigms of spatial development of contemporary cities. In consequence, actions are taken to improve the quality of city landscape and revitalise vacant areas. This study approaches the process of city regeneration as transformation and supplementation of the existing urban structure as well as creation of multifunctional, structurally, socially and ecologically sustainable spaces. The article presents the problem of creation of new-inner city residential areas. The study was conducted on three housing estates located in post-industrial and post-military areas: Harbourside Development in Bristol (UK), City Park and Ułańskie Estate in Poznań (Poland) and Browar Gdański in Gdańsk (Poland). The article includes analyses of relations between the estates and their surroundings, spatial structure parameters and architectural, urban and scenic characteristics. It includes assessment of the legibility, consistency, diversity and quality of the urban landscape.
\end{abstract}

Keywords

City landscape $\cdot$ public space $\cdot$ urban regeneration $•$ Bristol $•$ Poznań $•$ Gdańsk

(C) University of Warsaw - Faculty of Geography and Regional Studies
Elżbieta Raszeja ${ }^{1}$ Joanna Badach ${ }^{2}$

Department of Architecture and Urban Planning, Faculty of Architecture and Design, University of the Arts in Poznań, Poznań, Poland e-mail: elzbieta.raszeja@uap.edu.p

${ }^{2}$ Department of Urban Design and Regional Planning, Faculty of Architecture,Gdańsk University of Technology, Gdańsk, Poland e-mail: joanna.badach@pg.edu.pl

Received: 6 March 2018

Accepted: 30 July 2018
Introduction

After decades of crisis and the rapid depopulation of cities, we have begun observing the revival of inner city areas in recent years (Bromley et al. 2007; Rae 2013; Storper \& Manville 2006; Tallon \& Bromley 2004). Depressed inner city districts are being revitalised and rediscovered by inhabitants returning from the suburbs not only because of the locational advantages but also because of their diverse functional offer and specific urban lifestyle (Bromley et al. 2007; Fishman 2005). In reference publications, this phenomenon is referred to as reurbanisation (Buzar et al. 2006; Kabisch et al. 2010; Rérat 2012). Accompanying it is a need to change the approach to urban policy, acquire or develop new housing and service resources in degraded or unused areas, and create multifunctional public spaces that meet contemporary inhabitants' expectations. Urbanists and politicians began to use new planning and design tools to propose alternative solutions to uncontrolled urban expansion and the erosion of surrounding areas, offering to add more and better housing in inner city areas and take actions to improve the quality of city landscape and social structures (Howley 2009). Apart from that, the new paradigm of urban development was based on participatory aspirations of civil society arising from city inhabitants' increasing awareness and their need to exert real influence on urban policy (Billert 2012).

This article discusses the idea of a compact city, which is implemented by urban space recovery. This concept can be applied through the transformation of degraded post-industrial and post-military areas into multifunctional and structurally, socially and ecologically sustainable spaces. This approach is based on certain basic research assumptions which define the range of the study. The research is focused on two housing estates which were built in recent years in big cities in Poland. One of them is located in a post-industrial area in Gdańsk; the other can be found in a post-military area in Poznań. The comparative analysis was conducted by referencing an estate built in the former harbour and shipyard in Bristol (UK), an example of new British urban planning.

The article presents different approaches for taking advantage of an area's potential and making use of the analysed space, and it compares them with contemporary urban planning concepts. The authors analysed the new urban landscape created through the recovery of degraded spaces by considering different aspects of the revitalisation, e.g. nature and ecology, history and culture, composition and visual, perceptive as well as social characteristics. The degree and range of formation of spaces for social integration and the creation of a distinct city image were the basic criteria for assessment of landscape-beneficial actions. The following research questions were posed: How did the space recovery proceed in the three cities? How did the landscapebeneficial actions manifest? Did the actions create a new quality of urban space (urban structure and social space)? Was the potential of these areas thoroughly identified?

The aim of this article is to present the results of the analysis of the structure of urban space in three different housing estates built in post-industrial and post-military areas, as well as of the actions taken to create a new urban landscape. The indirect research objectives were as follows: 1 ) identification of the traits and parameters of the spatial structure of these estates and their architectural and scenic determinants, 2) identification and assessment of their relationship with the surrounding areas, 
3) assessment of the legibility and consistency of the urban composition, 4) assessment of the method and adaptation of the historical structure, 5) assessment of the diversity and attractiveness of the space created and assessment of the quality of landscape-beneficial solutions.

\section{Theoretical and practical context}

The postmodernist approach to urban planning included new trends which rejected modernist rationalism and its abandonment of historical and cultural models. New Urbanism was the first trend built on a strong programmatic and intellectual basis that promoted the creation of traditional, functionally diversified spaces which stimulated social interactions (Kelbaugh 2013; Lund 2003; Talen 2005). There were also other trends which emphasised sustainable development and environmental problems, e.g. Landscape Urbanism and Ecological Urbanism (Barnett 2013). The former trend is noteworthy for its new approach to the concept of a contemporary city, where the landscape is interpreted not only as a product of nature, culture and a perception model but also as an element of design (Turner 1996; Waldheim 2016). In this approach, urban design, landscape planning, and architecture are not limited to aesthetics or the reinforcement of natural structures, but serve to provide a basis for inhabitants' creativity and sensitivity as they inspire actions to preserve and strengthen the scenic values of the city in a broader sense (Grant Associates 2017; Kelbaugh 2013).

After decades of decentralisation and urban sprawl, contemporary urbanism promotes the idea of a compact city, which is developed through internal transformation rather than further territorial expansion. The essence of this vision is a prosperous, well-balanced and lively city with a diversified and dense structure, which exerts the smallest possible influence on the natural environment (Howley 2009; Zlonicky \& Vancutsem 2009). In recent years, this widely accepted concept has been expanded to the point that connectivity has become a key theme, with compact urban structure as only one of its many elements. This new vision of cities in the $21^{\text {st }}$ century treats connectivity as a complex network referring to historical continuity as well as various social, economic and environmental aspects. The Connected City concept comes from the revival in urban planning of an ideology that focuses on preventing the isolation and degradation of some city areas and developing social structures and landscapes in a city based on its specific character (eds Majda \& Mironowicz 2017; The New Charters of Athens 2003).

These urban planning ideas and concepts can be observed in situ in the United Kingdom. For several decades, there have been signs of urban revival, especially in terms of the development of social structures and cultural vitality, as a consequence of intensified actions in urban planning and housing policy (Cento Bull, A. and Jones 2006; Ellis \& Henderson 2014). This process began in the late 1970s when two documents were approved: "White Paper: Policy for the Inner City" (Great Britain. Department of the Environment 1977) and "Inner Urban Areas Act" (Great Britain 1978). The former concentrated on remedies for the inner city crisis (Tallon 2010), while the latter established partnerships between local and national authorities to quickly identify local problems and prepare action programmes to solve them (Lund 2016). In the 1970s and 1980s, British planning was characterised by deregulation and individual projects ("the project-led phase"); in the 1990s, there was much more emphasis put on implementing whole plans ("the plan-led phase"). Later, the authorities continued the development of urban spatial and institutional structures to guarantee the effectiveness of planning processes (Adams \& Watkins 2002; Jones \& Evans 2013).

In 1999, a report titled "Towards an Urban Renaissance", published by the Urban Task Force, formulated the assumptions of the new urban policy. It marked an important turning point in the development of British cities as its main recommendation was to create the largest possible number of housing and service resources in urbanised areas. Along with this, it recommended improving the attractiveness of city districts, creating diverse, multifunctional areas, improving pedestrian and cyclist infrastructure, developing the public transport system, and limiting car traffic in city centres (UTF 1999).

Following the report, the creation of residential structures and the introduction of more residents within inner-city districts, referred to as residentialisation, was thus seen as the main objective of urban regeneration programmes. The idea is meant to induce urban revival, reduce urban sprawl and re-use vacant land and buildings. The creation of socially sustainable communities in the city centre is also emphasised (Bromley et al. 2005; Couch 1999; UTF 1999). The areas of concern for regeneration programmes are post-industrial sites that have become disused in many European cities following economic transformations (Ganser \& Williams 2007). Nowadays, these sites represent potential, having space suitable for the creation of new residential and commercial structures. Numerous projects have already been developed on previously industrial sites, including the London Docklands (Butler 2007; Church 1988) or Thames Gateway (Dixon 2007; Raco \& Henderson 2006).

In the presented study, the city of Bristol was chosen as an example of British urban policy at work, based on the implementation of the aforementioned planning priorities and methods. The urban transformation of the city and revitalisation of the Avon riverbanks began in the 1980s as local authorities in Bristol began promoting the compact city concept to improve spatial and social integration. Simultaneously, they implemented various environmentally friendly actions to make the city a good place to live. In 2015, city authorities received the European Green Capital Award for their engagement in sustainable development as well as the development of creativity, culture and innovations (Raszeja 2017; Tallon 2007). The estate, built in the former harbour and shipyard in Bristol, was used as a point of reference to evaluate two examples of urban regeneration in Poland, in which the development of residential structures was used as their foundation. Since 2000, the previously spontaneous and disorganised process of revitalisation of postindustrial areas in Poland has become a planned activity included in strategy papers as well as in local, regional and national revitalisation programmes, employing a developed theoretical framework and practical tools (e.g. (Ministerstwo Inwestycji i Rozwoju 2015; Sejm Rzeczpospolitej Polskiej 2015)). It has not been restricted to post-industrial sites but has also included many post-military areas and vacant railway premises (Gasidło 2008). The aim of the implemented transformations of these areas is formulated not only in economic terms but includes environmental, cultural, social and landscape-related issues (Gasidło \& Rostański 2014).

\section{Study area and methods}

In the article, three estates are analysed: Harbourside Development in Bristol (UK), City Park and Ułańskie Estate in Poznań (Poland), and Browar Gdański Estate in Gdańsk (Poland). All three areas are located within the inner city zones, not far away from the historical centres, which can be easily accessed by roads (Fig. 1). They had the same genesis originally, these were industrial or military areas. However, as a result of political, social and economic changes, they became non-functioning and fell into disrepair over the years. Due to their inner city location, good access, attractiveness to investors, land value, and historical and cultural value, these areas underwent redevelopment to offer housing and services. The areas under analysis differed in the local authorities' approach to revitalising 

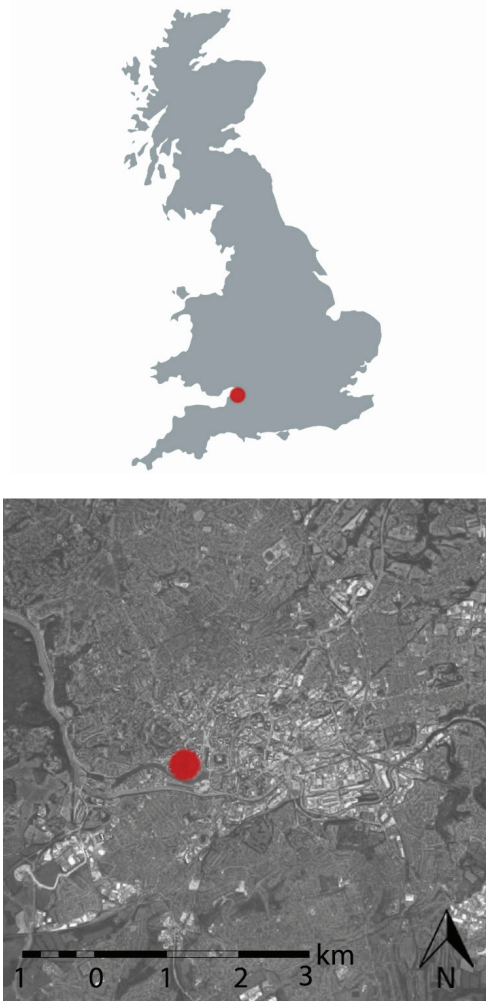
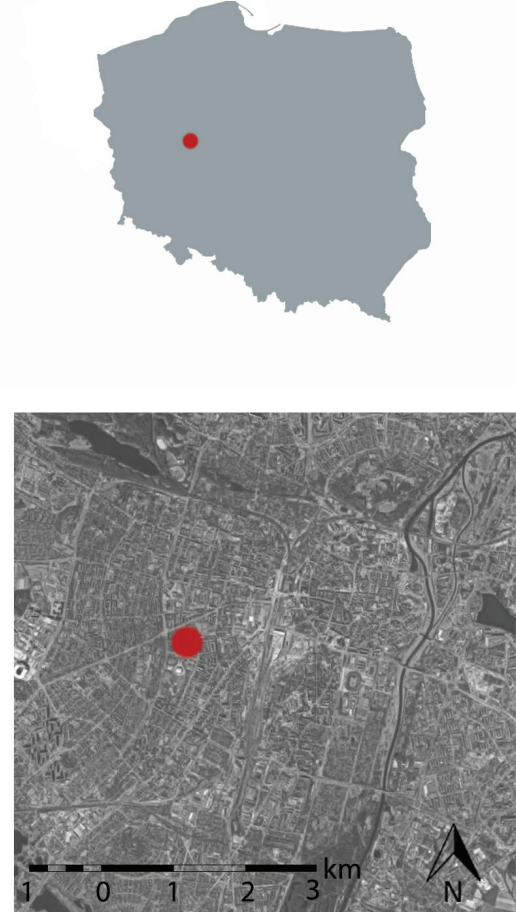
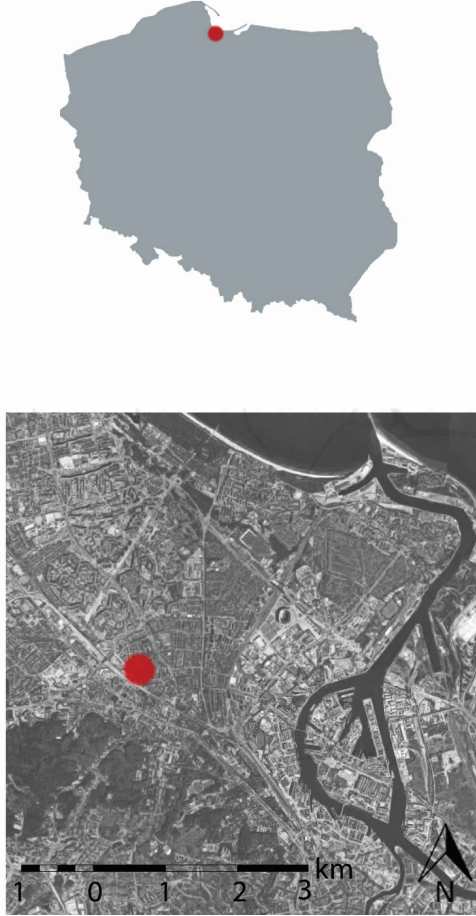

Figure 1. The location of the study areas within the country and the city: 1 - Bristol (UK), Harbourside Development 2 - Poznan (Poland), City Park and Ułańskie Estate, 3 - Gdańsk (Poland), Browar Gdański Estate. Source: own elaboration based on: www. google.com/maps

the urban space. The authors of this study investigated these differences.

As mentioned above, the Harbourside Development estate is the reference point for analysis and assessment of the selected Polish estates. This multifunctional housing complex was built in 2001 on the River Avon as part of the revitalisation of the historical Bristol waterfront. The area of more than 7 hectares of neglected docklands and old gasworks was transformed into an attractive housing and service space connected with the urban green space system, riverside roads and urban public spaces.

The City Park and Ułańskie Estate in Poznań (Grunwald district) is a complex of housing and services constructed on the site of an old military barracks, built in the $19^{\text {th }}$ century. It is located in the district of Grunwald and bordered by Grunwaldzka Street to the north, Wojskowa Street to the west and Ułańska Street to the east. It neighbours the Arena sport complex and Jan Kasprowicz Park. Between 2006 and 2008, the historical buildings were renovated and adapted to new functions.

The Browar Gdański housing estate in Gdańsk (Wrzeszcz district) was built between Kilińskiego, Grażyny, Gołębia and Wajdeloty streets at the site of an old brewery that dated back to the $18^{\text {th }}$ century. In 2006, a developer purchased this land. The local land use plan approved in 2007 included rules for the protection of historical buildings, preservation of the character of the post-industrial complex, and creation of a high-quality public space (Sztuka Architektury 2015; UMG 2017). The investment began in 2014 and it is still in progress.

Between 2015 and 2017, a field study was conducted. It involved detailed photographic documentation, inventory and initial analyses of the urban and functional structures of these areas. The field study was supplemented with an archive query and the collection of necessary materials and information about all three estates, available in publications and online. The next stage of research involved a literature review of contemporary ideas in urban development and current knowledge of urban planning and design. The authors of the article collected materials and documentation for a critical analysis of case studies, chiefly based on qualitative methods. First, the authors analysed various connections between the estates and the urban structure, specifically looking at aspects relating to functionality, mobility, history, culture, nature and composition. This involved the identification of structural elements located in the immediate vicinity of the estates which were important for their functioning. Detailed analysis of the estates comprised the following aspects: - the range and form of adaptation, the permanence of structures and historical elements,

- the functional and spatial structure,

- the urban composition (nodes, axes and dominants),

- access to the estates (enclosures, entrances, pedestrian routes),

- public, semi-private and private spaces - size and proportions,

- vegetation - form, access and degree of arrangement/ naturalness,

- environmentally friendly solutions (creation of the local climate, phytoremediation, drainage),

- perception of landscape - elements creating an image, distinguishing features,

- social activity - frequented places.

The quantitative investigations were limited to the following aspects: the built-up area, development intensity, the share of bioactive surface, the degree of closure (the length of enclosures vs. the length of the estate boundaries), and the share of 
Table 1. Essential information and urban parameters of the estates. Source: own elaboration based on (Agrobex 2014; City Park 2017; Cullinan Studio 2017; Dynamo Produce 2012; Grant Associates 2017; Przedsiębiorstwo Budowlane Górski 2017; Sztuka Architektury 2015; Urbanity 2015)

\begin{tabular}{|c|c|c|c|}
\hline $\begin{array}{c}\text { Selected information and } \\
\text { urbanparameters }\end{array}$ & $\begin{array}{c}\text { Bristol (UK) Harbourside } \\
\text { Development }\end{array}$ & $\begin{array}{l}\text { Poznań (Poland) City Park } \\
\text { and Ułańskie Estate }\end{array}$ & $\begin{array}{c}\text { Gdańsk (Poland) Browar } \\
\text { Gdański Estate }\end{array}$ \\
\hline Designer & $\begin{array}{c}\text { Cullinan Studio (urban } \\
\text { planning and architecture), } \\
\text { Grant Associates (landscape } \\
\text { architecture) }\end{array}$ & $\begin{array}{l}\text { Sławomir Rosolski Design } \\
\text { Studio (architecture) } \\
\text { Rock \& Flower Studio } \\
\text { (landscape architecture) }\end{array}$ & Dynamo Produce \\
\hline Construction time & since 2001 & 2006-2008 & since 2014 \\
\hline $\begin{array}{l}\text { Distance from centre } \\
\text { 1) straight line distance }(\mathrm{km}) \\
\text { 2) walking time or travel } \\
\text { time by public transport }\end{array}$ & $\begin{array}{l}\text { 1) about } 0.6 \mathrm{~km} \\
\text { 2) } \\
\begin{array}{l}10 \text {-minute walk to the } \\
\text { cathedral, } 15-\text { minute } \\
\text { walk to the old town }\end{array}\end{array}$ & $\begin{array}{ll}\text { 1) } & \text { about } 3 \mathrm{~km} \\
\text { 2) } & 15 \text {-minute tram journey to } \\
& \text { Old Market Square }\end{array}$ & $\begin{array}{l}\text { 1) about } 4 \mathrm{~km} \\
\text { 2) } 15 \text {-minute tram journey to } \\
\text { the Old Market Square }\end{array}$ \\
\hline Cultural distinguishing features & $\begin{array}{l}\text { Harbour architecture and } \\
\text { infrastructure }\end{array}$ & Military architecture & Industrial architecture \\
\hline Natural distinguishing features & $\begin{array}{c}\begin{array}{c}\text { Unique environmentally friendly } \\
\text { solutions - plant habitats }\end{array} \\
\end{array}$ & Alleys and roadside espaliers & $\begin{array}{c}\begin{array}{c}\text { Part of the Strzyża Brook and } \\
\text { old tree stand }\end{array} \\
\end{array}$ \\
\hline Estate area & $>7$ ha & $>6$ ha & $>3$ ha \\
\hline Height of buildings & 3-8 storeys & $1-5$ storeys & $1-5$ storeys \\
\hline Share of historical buildings & None & About $40 \%$ of the built-up area & About $25 \%$ of the built-up area \\
\hline
\end{tabular}

services (available to the general public). Essential information about individual estates and the basic parameters of their urban structure is included in Table 1 and compared graphically in Figs. 2, 3, 4 .

\section{Results}

The area covered by the three estates under study is determined by specific local natural conditions (hydrographic network, terrain and land coverage), which are strongly related to cultural conditions and the locations' earlier functions. The industrial and military past which remained in the urban forms, elements of buildings and engineering constructions was creatively used in contemporary architectural and urban solutions. In each case, there are different references to historical forms which depend on their state of preservation and their value. The designers used different programmatic, functional and formal solutions. As a result, they created public spaces with varying levels of attractiveness, social acceptance and consistency with the urban structure and city landscape (Fig. 2, 3, 4).

\section{Bristol (UK) - Harbourside Development}

The designers of the Bristol Harbourside Development emphasised that community was an important factor in planning the estate structure, so they started with extensive public consultation. This outreach resulted in the construction of a multifunctional complex of buildings of high utility, which provided housing, services, and recreational space (Fig. 5). All inhabitants had access to the new attractive public space because there were neither physical barriers (only one of the housing complexes was enclosed) nor economic ones (the prices of houses and services were diversified). The development is connected with the urban structure of the inner city by a system of pedestrian routes. The network of green infrastructure strengthened the city ecosystem (Cullinan Studio 2017; Grant Associates 2017). In terms of foundational ideas, the project was based on legible narration, emphasising the relationship of the city with water as well as a sequence of landscape interiors and public spaces. Connections with the dominants of the urban structure of the city are important elements of the composition - there are scenic axes leading to

\section{A - the urban composition}

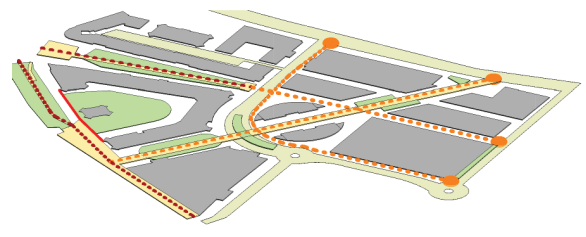

$B$ - the land use

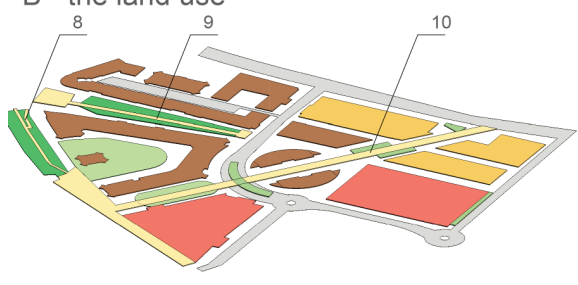

C - the spatial structure

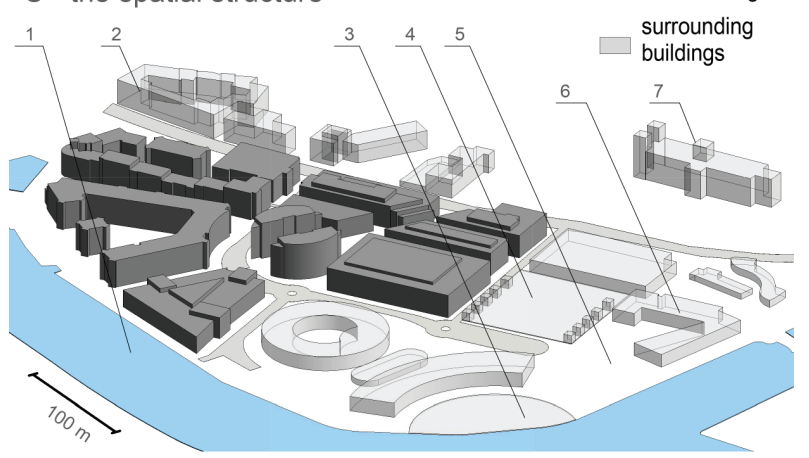

Figure 2. Bristol (UK), Harbourside Development: 1 - River Avon, 2 - Bristol College, 3 - Amphitheatre, 4 - Millennium Square, 5 - Waterfront Square, 6 - V-Shade (shops and restaurants), 7 Cathedral, 8 - Waterfront route, 9 - Brunel Mile, 10 - Cathedral walk. Source: own elaboration based on (Cullinan Studio 2017; Grant Associates 2017). 


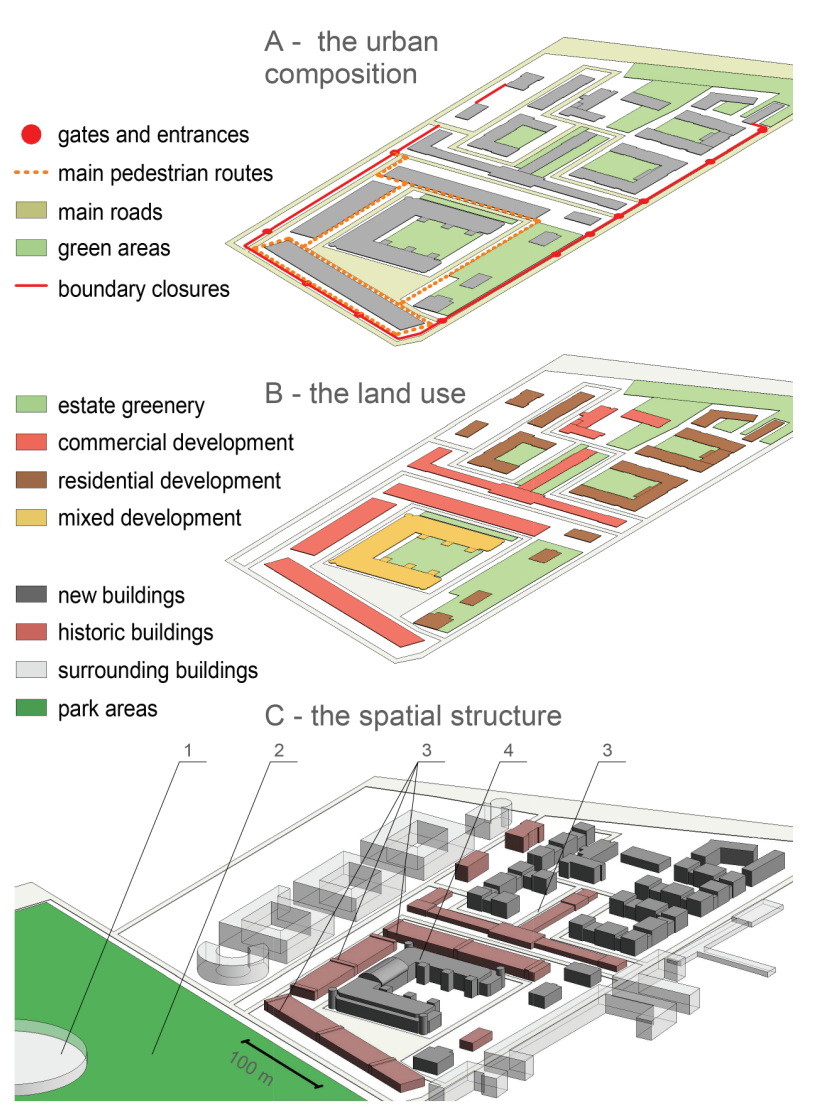

Figure 3. Poznań (Poland), City Park and Ułańskie estate: 1 Sport complex "Arena", 2 - Kasprowicz Park, 3 - Shops and restaurants, 4- Hotel and sport facilities. Source: own elaboration based on (Agrobex 2014; City Park 2017; Urbanity 2015).

the cathedral, harbour and the Great Britain museum ship, as well as wide scenic openings to the River Avon (Fig. 6). City art also plays a significant role in the space. Outstanding European artists were employed to design the integration of individual places with the city landscape. Apart from spatial, scenic, architectural and artistic concepts, the design also includes special environmentally friendly solutions: sustainable urban drainage, which directs the flow of rainwater from roofs into a system of irrigation canals, and adequately selected plant habitats (an extensive green wall and reed beds, which are responsible for microclimate regulation, water retention and maintenance of biodiversity (Grant Associates 2017).

\section{Poznań (Poland) - City Park and Ułańskie Estate}

At the beginning of the $21^{\text {st }}$ century, a new urban project was implemented at the site of a former military barracks built in the $19^{\text {th }}$ century. It consists of two independent parts: a complex of suites and service facilities and a complex of multi-family buildings. The City Park complex is composed of reconstructed post-military buildings and new extensions. The character of the historical military architecture was preserved in the form of buildings (the scale and proportion), material (mostly red brick) and architectural details. The historical buildings were adapted to serve as hotels, shops, restaurants, cafes and sports facilities (Fig. 7). South of the complex is Ułańskie Estate, where multifamily buildings were erected at the site of the barracks. Their architecture makes reference to the military building style with the predominance of clinker bricks (ed. Pazder 2008; Poznań - atlas

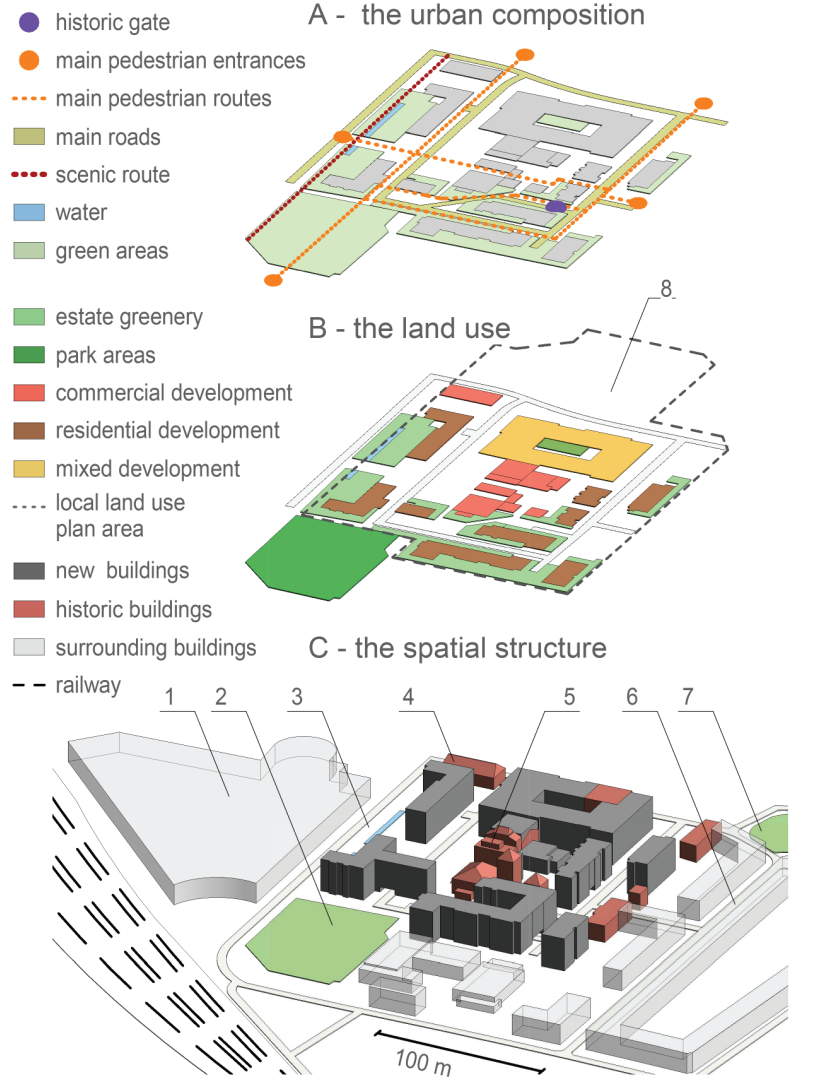

Figure 4. Gdańsk (Poland), Browar Gdański estate: 1 - Shopping centre Metropolia, 2 - Kuźniczki Park, 3 - Strzyża Brook, 4 Kindergarten, 5 - Old brewery complex, 6 - Historic residential buildings, 7-City park, 8-Area of further residential development. Source: own elaboration based on (Dynamo Produce 2012; Przedsiębiorstwo Budowlane Górski 2017; Sztuka Architektury 2015).

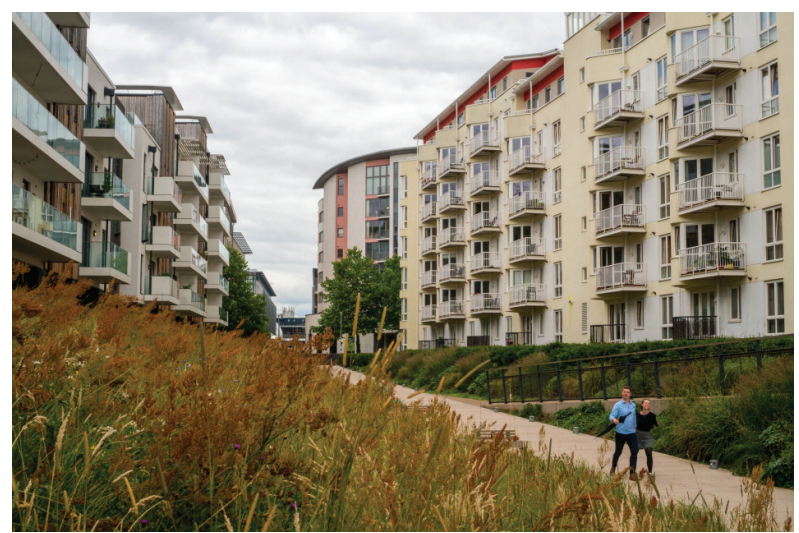

Figure 5. Bristol (UK), Harbourside Development - pedestrian route in the residential area. Source: photo J. Badach.

aglomeracji 1:15.000 2008). The construction of the estate was supervised by the City Conservator. The new buildings included details and materials corresponding to the character of the old buildings, e.g. brick, glass and steel (Fig. 8). As a result, both complexes retain a uniform post-industrial character. Green spaces were carefully designed and arranged so that they would 


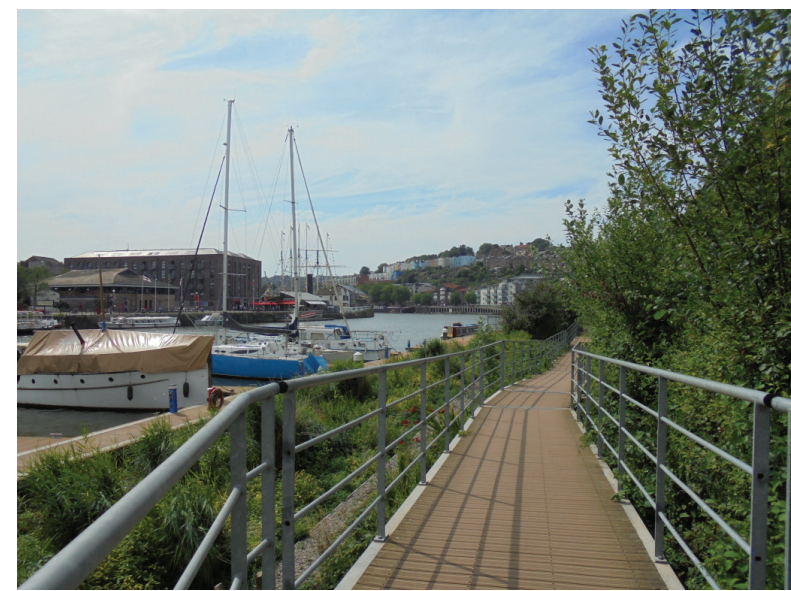

Figure 6. Bristol (UK), Harbourside Development - landscape route on the Avon river. Source: photo E. Raszeja

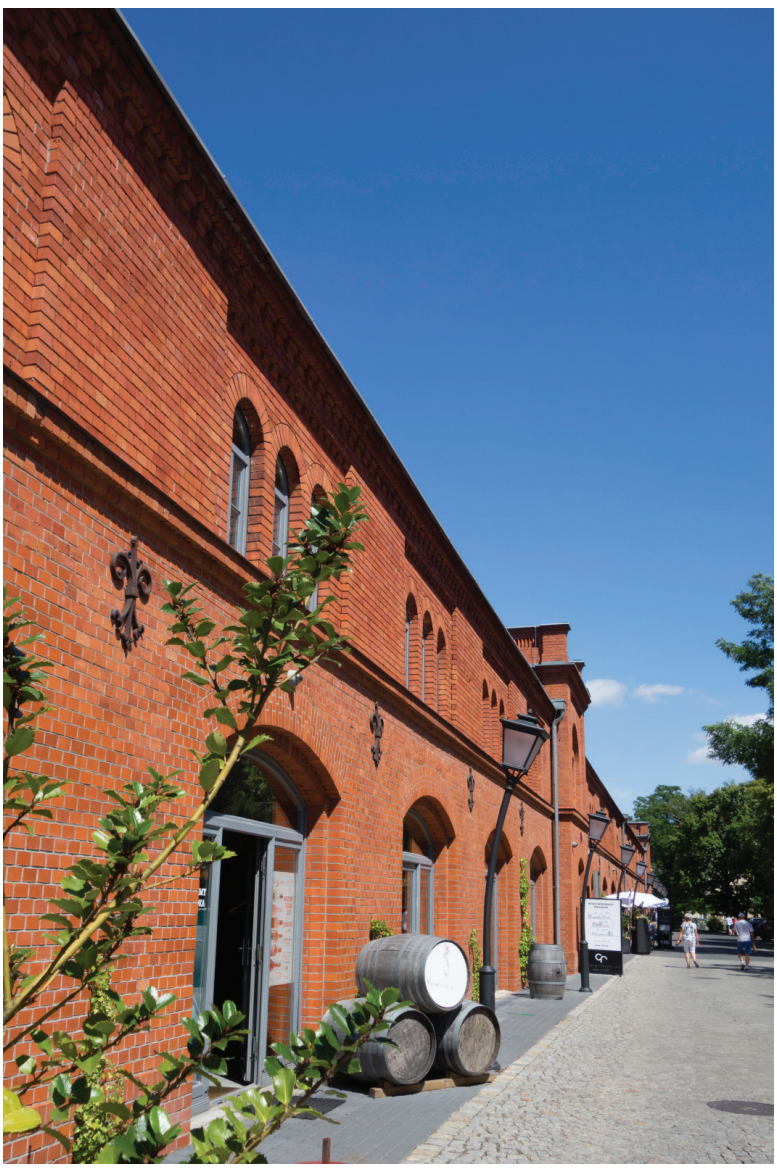

Figure 7. Poznań (Poland), City Park - shops and restaurants in the historical military buildings. Source: photo E. Raszeja

match the cosy residential interiors and service areas. The whole complex is surrounded by a wall partially original to the barracks and supplemented with a new, full enclosure. The complex is semi-open. All the gates are closed at night, while during the day, only the public space is open. There are different housing prices - there are moderately-priced flats in Ułańskie Estate, whereas the City Park complex has mostly luxurious flats and suites.

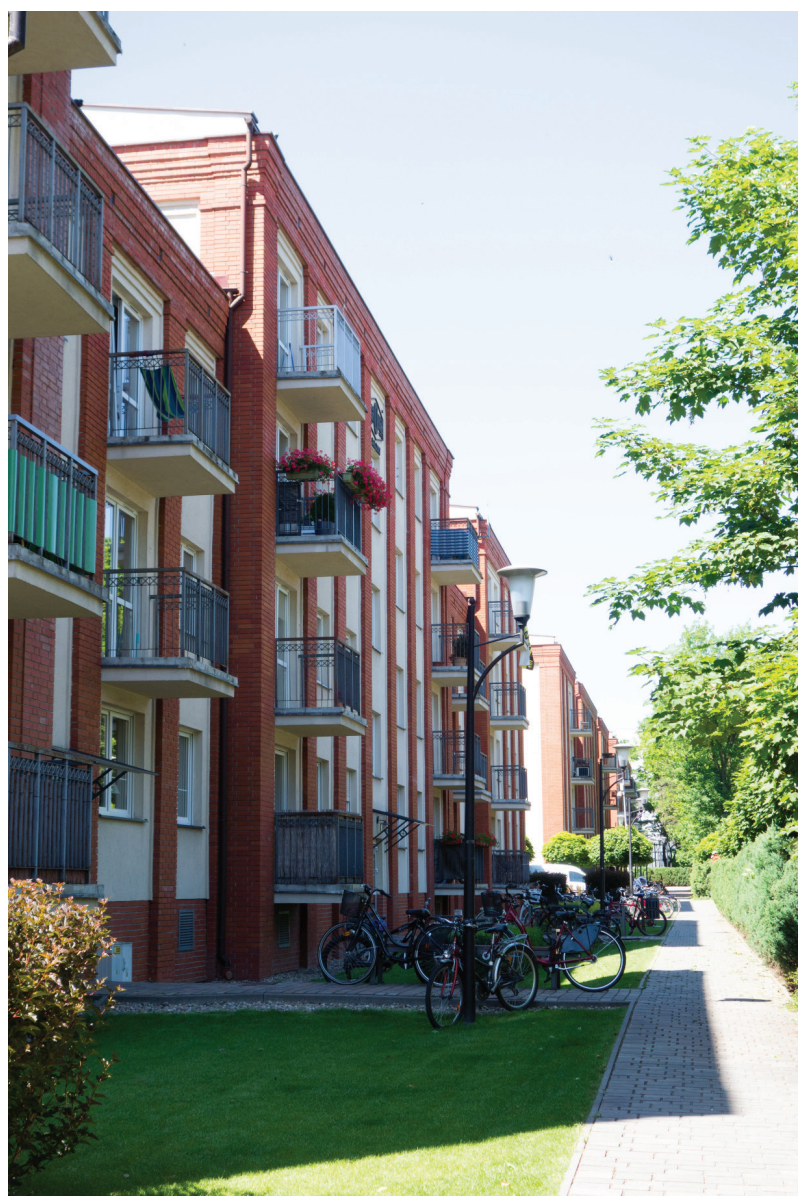

Figure 8. Poznań (Poland), Ułańskie Estate - multi-family buildings. Source: photo E. Raszeja

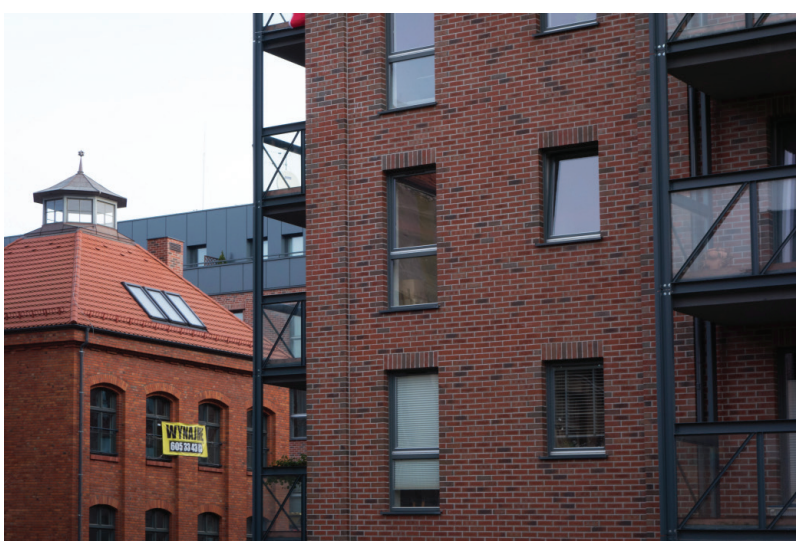

Figure 9. Gdańsk (Poland), Browar Gdański Estate - new multifamily buildings next to the old brewery building. Source: photo J. Badach

\section{Gdańsk (Poland) - Browar Gdański estate}

In 2006, a developer purchased the plot of land where an old brewery had been situated in Gdańsk-Wrzeszcz. The local community suggested the land use plan, which was approved in 2007. It included a large number of provisions to protect the unique character of the post-industrial complex, create highquality buildings with homes and services, and connect its public 


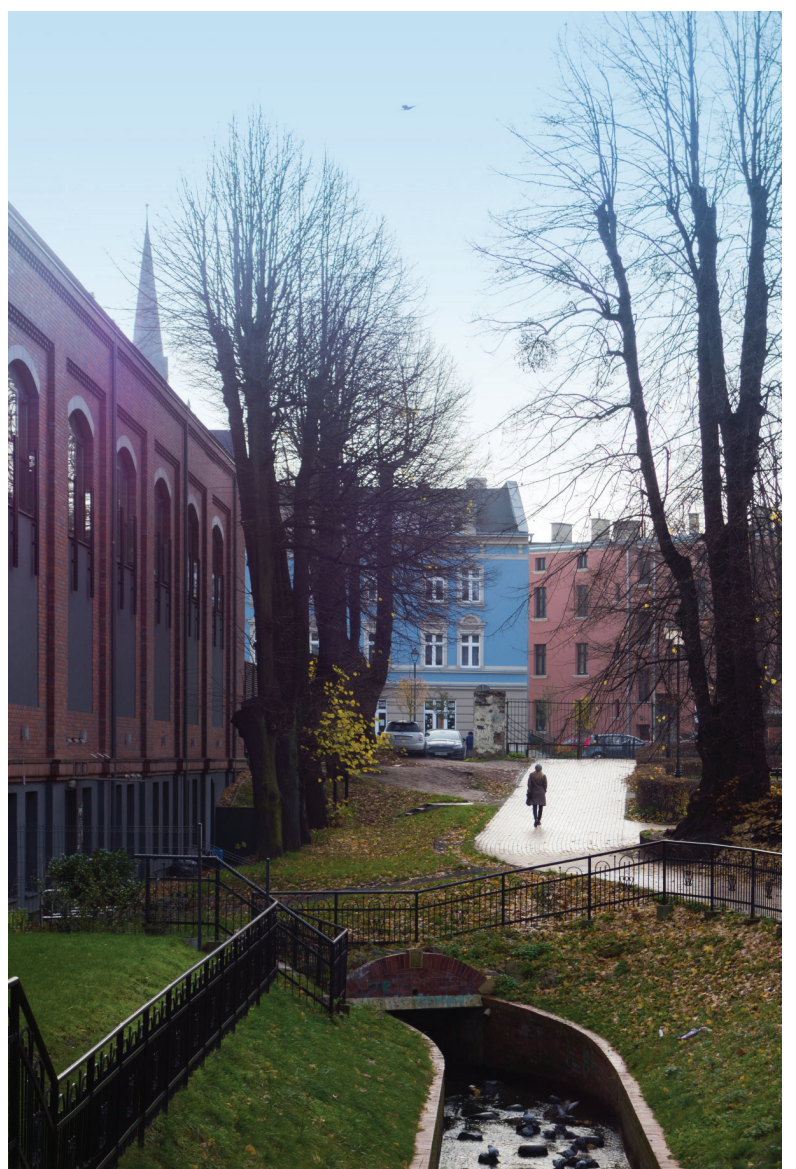

Figure 10. Gdańsk (Poland), Browar Gdański Estate - scenic pedestrian route on the Strzyża Brook. Source: photo J. Badach space with neighbouring Kuźniczki Park (Sztuka Architektury 2015; UMG 2017). The plan required that the historical spatial structure of buildings and vegetation be preserved and supplemented. It also required that historical buildings be connected by pedestrian routes, the old entrance to the brewery be restored and the open fragment of the Strzyża Brook preserved. Another important element of the plan was the provision that the brewing tradition of the place should be preserved and a beer workshop should be located at the estate (UMG 2017). The form and scale of buildings in Browar Gdański estate match the character of the place and are consistent with the idea of New Urbanism (Fig. 9). Harmonious urban interiors, dominants, architectural accents and scenic axes make a legible and consistent composition. The designers created a system of friendly public spaces which integrate the estate with the city structure. The scenic and functional relationship with the surroundings is strengthened by legible entrances to the estate and few enclosures. The quality of space is influenced by the state of preservation of the historical structure and the high standard of aesthetic solutions, as seen in the carefully selected details and materials. The identity of the place is strengthened by natural elements, such as the Strzyża Brook (Fig. 10). It is also strengthened by cultural elements the buildings of the old brewery. Some of them preserved their historical function, whereas others were adapted to provide new urban functions - homes and services. Nevertheless, the high prices of flats and business premises has limited the number of residents and users of this area.

\section{Discussion and conclusions}

The research showed that the recovery of unused and degraded urban spaces has a multidimensional nature. The assessment of the outcomes depends on the criteria used. In the context of a compact city, which relies on the process of internal transformation, post-industrial and post-military areas provide valuable opportunities for implementation of the concept. At the same time, these opportunities might be limited to the area of the future investment and remain unconnected to the complex

Table 2. An assessment of landscape-beneficial actions in the estates studied. Source: own elaboration

\begin{tabular}{|c|c|c|c|}
\hline $\begin{array}{c}\text { Dimension of landscape- } \\
\text { beneficial actions }\end{array}$ & $\begin{array}{c}\text { Bristol (UK) Harbourside } \\
\text { Development }\end{array}$ & $\begin{array}{l}\text { Poznań (Poland) City Park } \\
\text { and Ułańskie Estate }\end{array}$ & $\begin{array}{c}\text { Gdańsk (Poland) Browar } \\
\text { Gdański Estate }\end{array}$ \\
\hline $\begin{array}{l}\text { Historical and cultural } \\
\text { continuity }\end{array}$ & $\begin{array}{l}\text { Restoring the character } \\
\text { (tradition) of the place, } \\
\text { no historical buildings, } \\
\text { reconstruction of the historical } \\
\text { waterfront }\end{array}$ & $\begin{array}{c}\text { Adaptation of a complex } \\
\text { of historical buildings, } \\
\text { maintenance of the urbanistic } \\
\text { system and architectural } \\
\text { forms, careful selection of } \\
\text { materials and details }\end{array}$ & $\begin{array}{c}\text { Maintenance and adaptation } \\
\text { of a few historical buildings in } \\
\text { the central part of the complex, } \\
\text { reconstruction of historical } \\
\text { elements, careful selection of } \\
\text { materials and details } \\
\end{array}$ \\
\hline $\begin{array}{l}\text { Integration with the urban } \\
\text { structure and public space of } \\
\text { the city (access, activity) }\end{array}$ & $\begin{array}{c}\text { Inclusion in the city space, } \\
\text { important element of urban } \\
\text { structure, open access, active } \\
\text { multifunctional space }\end{array}$ & $\begin{array}{c}\text { Exclusive space, limited } \\
\text { access, physical barriers } \\
\text { (gates, enclosures), economic } \\
\text { barriers (prices) and mental } \\
\text { barriers (offer for few people) }\end{array}$ & $\begin{array}{l}\text { Connected with the city space, } \\
\text { accessible (pedestrian route), } \\
\text { recovery expected, physical } \\
\text { barrier (shopping mall) }\end{array}$ \\
\hline $\begin{array}{l}\text { Composition (visual values, } \\
\text { distinguishing features) }\end{array}$ & $\begin{array}{c}\text { Open composition, strong } \\
\text { compositional relationship } \\
\text { with the city landscape (scenic } \\
\text { axes, dominants) }\end{array}$ & $\begin{array}{c}\text { Closed composition, } \\
\text { attractively formed internal } \\
\text { courtyards (sequence of } \\
\text { architectural and landscape } \\
\text { interiors) }\end{array}$ & $\begin{array}{c}\text { Composition based on a } \\
\text { sequence of architectural and } \\
\text { landscape interiors, reference } \\
\text { to the urban structure in } \\
\text { Wrzeszcz district }\end{array}$ \\
\hline $\begin{array}{l}\text { Ecology (biodiversity, } \\
\text { naturalness) }\end{array}$ & $\begin{array}{c}\text { Diverse forms and species } \\
\text { composition of vegetation, } \\
\text { riverside habitats, drainage, } \\
\text { phytoremediation, climate } \\
\text { regulation }\end{array}$ & $\begin{array}{l}\text { Only composed complexes of } \\
\text { vegetation with diverse and } \\
\text { attractive forms and species } \\
\text { (alleys, espaliers, green } \\
\text { squares) }\end{array}$ & $\begin{array}{c}\text { Composed and diverse } \\
\text { forms vegetation (mostly low- } \\
\text { growing plants), making use } \\
\text { of water, connection with the } \\
\text { neighbouring park }\end{array}$ \\
\hline
\end{tabular}


conditions of the entire city. Undoubtedly, the adaptations of the post-military buildings in Poznań and post-industrial areas in Gdańsk are examples of the successful revitalisation of historical structures and the creation of high-quality contemporary architecture. However, we must ask the question whether recovering these spaces was successful for the whole city or only for a limited group of inhabitants.

If we refer to the aforementioned urban planning experience in the United Kingdom, we can locate these examples at individual stages of their development and improvement of their methods and tools (Adams and Watkins 2002; Jones and Evans 2013). The process of recovery of these areas in the Polish cities can be referred to as the reductionist phase, which predominated in the UK in the 1970s and 1980s. It was characterised by individual developer-led investments based on partial local land use plans or land development conditions and is also known as the projectled phase. On the other hand, the process of the construction of the complex in Bristol is an example of the holistic phase, which has predominated since the 1990s. In this phase, investments are preceded by a consistent planning vision based on an analysis of the potential of a particular place. This is also known as the plan-led phase. At present, we can observe a completely new approach, i.e. the community-based phase, where the process of planning spatial solutions is based on extensive public consultation (Cilliers \& Timmermans 2014; Deakin 2012).

Harbourside Development in Bristol is an urban project based on this new approach. It shows that the aspect of social creation is as important as architectural and scenic forms in achieving a socially consistent and inclusive space (Lefebvre 2009). The identity of a place can be created by emphasising its local values and distinguishing cultural features and then matching them with the new city landscape. According to Rem Koolhaas, an outstanding Dutch architect and theoretician, the essence of urbanism is not to distribute objects and their functions in space, but to discover the potential of individual areas and to revive them through their potential (Koolhaas 2007). The aforementioned concept of a Connected City forces us to approach this problem from different perspectives, where connectivity is defined as a complex network of multidimensional relations. Likewise, we can also make a multidimensional analysis and assess the actions taken to recover space and create a new city landscape (Table 2).

\section{References}

Adams, D \& Watkins, C 2002, Greenfields, Brownfields \& Housing Development. Blackwell Publishing, Oxford, Malden.

Agrobex 2014, Apartementy - Lofty Ułańskie. Available from: <https://agrobex.pl/pl/lofty-ulanskie>. [16 October 2017].

Barnett, J 2013,'What's New About the New Urbanism?' in Charter of the New Urbanism, 2nd Edition,ed E Talen, McGraw Hill Professional, pp.1-8.

Billert, A 2012,'Kultura - Polityka - Rozwój O kulturze jako " dźwigni " polskich metropolii i regionów' in Kultura, polityka, rozwój: o kulturze jako dźwigni rozwoju społecznego polskich metropolii i regionów, eds S Szultka \& P Zbieranek, Instytut Badań nad Gospodarką Rynkową, Gdańsk, pp.20-28.

Bromley, RDF, Tallon, AR, \& Roberts, AJ 2007, 'New populations in the British city centre: Evidence of social change from the census and household surveys', Geoforum, vol. 38, no. 1, pp. 138-154.

Bromley, RDF, Tallon, AR, \& Thomas, CJ 2005, 'City Centre Regenetation through Residential Development: Contributing to Sustainability', Urban Studies, vol. 42, no. 13, pp. 2407-2429.

Butler, T 2007, 'Re-urbanizing London Docklands: Gentrification, suburbanization or new urbanism?', International Journal of Urban and Regional Research, vol. 31, no. 4, pp. 759-781.

Buzar, S, Ogden, P, Hall, R, Haase, A, Kabisch, S, \& Steinführer, A 2006, 'Splintering Urban Populations: Emergent Landscapes of Reurbanisation in Four European Cities', Urban Studies, vol. 44, no. 4, pp. 651-677.

Cento Bull, A\& Jones, B 2006, 'Social Capital, Urban Regeneration and Local Governance. A Comparison between Bristol and Naples', Urban Studies, vol. 43, no. 4, pp. 767-786.

Church, A 1988, 'Urban regeneration in London Docklands: a five-year policy review', Environment and Planning C: Government and Policy, vol. 6, no. 2, pp. 187-208.

Cilliers, EJ \& Timmermans, W 2014, 'The importance of creative participatory planning in the public place-making process', Environment and Planning B: Planning and Design, vol. 41, no. 3, pp. 413-429.

City Park 2017, City Park Poznań. Available from: <http://citypark. com.pl/historia/>. [15 October 2017].

Couch, C 1999, 'Housing Development in the City Centre', Planning Practice and Research, vol. 14, no. 1, pp. 69-86.
Cullinan Studio 2017, Bristol Harbourside Masterplan. Available from: <http://cullinanstudio.com/project/bristol harbourside_masterplan>. [22 October 2017].

Deakin, M 2012, 'The case for socially inclusive visioning in the community-based approach to sustainable urban regeneration', Sustainable Cities and Society, vol. 3, no. 1, pp. 13-23.

Dixon, T 2007, 'The Property Development Industry and Sustainable Urban Brownfield Regeneration in England: An Analysis of Case Studies in Thames Gateway and Greater Manchester', Urban Studies, vol. 44, no. 12, pp. 2379-2400.

Dynamo Produce 2012, Browar Gdański. Available from: <http:// www.dynamo.net.pl/browar-wrzeszcz-2007>. [22 October 2017].

Ellis, H \& Henderson, K 2014, Rebuilding Britain. Planning for a better future. Policy Press, Bristol.

Fishman, R 2005, 'The Fifth Migration', Journal of the American Planning Association, vol. 71, no. 4, pp. 357-366.

Ganser, R \& Williams, K 2007, 'Brownfield Development: Are We Using the Right Targets? Evidence from England and Germany', European Planning Studies, vol. 15, no. 5, pp. $603-622$

Gasidło, K 2008, 'Przekształcenia terenów poprzemysłowych efekty i perspektywy badań i działań', Problemy ekologii, vol. 12, no. 2, pp. 76-80.

Gasidło, K \& Rostański, K 2014, 'Idea minimalizmu w kształtowaniu terenów po eksploatacji górniczej', Przegląd górniczy, vol. 8, pp. 17-23.

Grant Associates 2017, Grant Associates - Bristol Harbourside. Available from: <http://grant-associates.uk.com/projects/ bristol-harbourside-landscape-masterplan/>. [22 October 2017].

Great Britain. Department of the Environment 1977, White Paper: Policy for the Inner City. London: H.M.S.O.

Great Britain 1978, Inner Urban Areas Act. London: H.M.S.O.

Howley, P 2009, 'Attitudes towards compact city living: Towards a greater understanding of residential behaviour', Land Use Policy, vol. 26, no. 3, pp. 792-798.

Jones, P \& Evans, J 2013, Urban regeneration in the UK, second edition. SAGE Publications, London.

Kabisch, N, Haase, D, \& Haase, A2010, 'Evolving Reurbanisation? Spatio-temporal Dynamics as Exemplified by the East 
German City of Leipzig', Urban Studies, vol. 47, no. 5, pp. 967-990.

Kelbaugh, D 2013,'Landscape Urbanism, New Urbanism and the Environmental Paradox of the Cities' in Landscape Urbanism and its Discontents. Dissimulating the Sustainable City, eds A Duany \& E Talen, New Society Publisher.

Koolhaas, R 2007,'The generic city, and whatever happened to urbanism?' in The Urban Design Reader, 2nd Edition, eds M Larice \& E Macdonalds, London and New York, pp.358-372.

Lefebvre, $\mathrm{H} 2009$, The production of space, Blackwell Publishing, Oxford - Malden - Carlton.

Lund, B 2016, Housing politics in the United Kingdom: Power, planning and protest, Policy Press, Bristol.

Lund, H 2003, 'Testing the Claims of New Urbanism: Local Access, Pedestrian Travel, and Neighboring Behaviors', Journal of the American Planning Association, vol. 69, no. 4, pp. 414-429.

Majda, T \& Mironowicz, I (eds) 2017, Manifesty Urbanistyczne. W poszukiwaniu modelu współczesnego miasta., Biblioteka. Towarzystwo Urbanistów Polskich, Warszawa.

Ministerstwo Inwestycji i Rozwoju 2015, Krajowa Polityka Miejska. Departament Polityki Przestrzennej, Warszawa.

Pazder, J (ed) 2008, Atlas architektury Poznania. Wydawnictwo Miejskie, Poznań.

Poznań - atlas aglomeracji 1:15.000 2008. CartoMedia/Pietruska \& Mierkiewicz, Poznań.

Przedsiębiorstwo Budowlane Górski 2017, Browar Gdański. Available from: <http://www.browargdanski.pl>. [22 October 2017].

Raco, M \& Henderson, S 2006, 'Sustainable urban planning and the brownfield development process in the United Kingdom: Lessons from the Thames Gateway', Local Environment, vol. 11 , no. 5, pp. 499-513.

Rae, A 2013, 'English urban policy and the return to the city: A decade of growth, 2001-2011', Cities, vol. 32, pp. 94-101.

Raszeja, E 2017,'From a vista to the "city ecosystem". Nature and landscape as elements which shape Bristol's urban structure.' in Materiały z ogólnoposlkiej konferencji naukowej 'Szacunek dla środowiska przyrodniczego istotnym elementem edukacji projektanta i architekta', Uniwersytet Artystyczny w Poznaniu, pp.82-91.
Rérat, P 2012, 'The New Demographic Growth of Cities: The Case of Reurbanisation in Switzerland', Urban Studies, vol. 49, no. 5 , pp. 1107-1125.

Sejm Rzeczpospolitej Polskiej 2015, Ustawa o rewitalizacji Dz.U. 2015 poz. 1777.

Storper, M \& Manville, M 2006, 'Behaviour, preferences and cities: urban theory and urban resurgence', Urban Studies, vol. 43, no. 8, pp. 1247-1274.

Sztuka Architektury 2015, Browar Gdański - stare i nowe mieszkania. Available from: <http://sztuka-architektury. pl/article/3153/browar-gdanski-8211-stare-i-nowemieszkania>. [15 October 2017].

Talen, E 2005, New Urbanism and American Planning: The Conflict of Cultures. Routledge, New York.

Tallon, AR 2007, 'Bristol', Cities, vol. 24, no. 1, pp. 74-88.

Tallon, AR 2010, Urban regeneration in the UK.

Tallon, AR \& Bromley, RDF 2004, 'Exploring the attractions of city centre living: Evidence and policy implications in British cities', Geoforum, vol. 35, no. 6 SPEC.ISS., pp. 771-787.

The New Charters of Athens 2003. Lisbon.

Turner, T 1996, City as Landscape: A Post-postmodern View of Design and Planning. E \& FN Spon, London.

UMG 2017, Urząd Miasta Gdańska - Plany zagospodarowania przestrzennego. Available from: <http://www.gdansk.pl/ zagospodarowanie-przestrzenne>. [7 November 2017].

Urbanity 2015, Poznań City Park. Available from: <http://www. urbanity.pl/wielkopolskie/poznan/city-park-c,b1541>. [15 October 2017].

UTF 1999, Towards an urban renaissance. Urban Task Force Report.

Waldheim, C 2016, Landscape Urbanism: A General Theory. Princeton University Press, Princeton and Oxford.

Zlonicky, P \& Vancutsem, D 2009,'Between tradition and vision: Urban trends and strategies of German Cities. The Munich Experience' in ISOCARP Review 04. Urban Growth without Sprawl. A Way towards Sustainable Urbanization. ISOCARP, Dalian. 